\title{
Improving Human Capital through Better Education to Support Indonesia's Economic Development
}

\author{
Latif Adam ${ }^{\mathrm{a}, *}$, Siwage Dharma Negara ${ }^{\mathrm{a}, * *}$ \\ a Indonesian Institute of Sciences (LIPI)
}

\begin{abstract}
Despite Indonesia's impressive economic growth, it still lags behind other countries with a similar income level in terms of the quality of its human capital. This paper argues that one key factor explaining this low quality of human capital relates to the lack of focus and clear strategies to develop its education system. This paper attempts to assess Indonesia's current state of human capital development with particular focus on its education sector. In order to benefit from its demographic bonus, Indonesia needs to to improve its current education and skill-training system. Better education and skill-training system will support the country's effort to reduce poverty and youth unemployment. The effectiveness of public spending in education should be improved to raise the quality of education. Indonesia needs to integrate its human capital development plan with its economic master plan.
\end{abstract}

Keywords: Human Capital; Poverty; Unemployment; Education; Development

\begin{abstract}
Abstrak
Meskipun mencatatkan pertumbuhan ekonomi yang mengagumkan, kualitas sumber daya manusia Indonesia masih tertinggal dibandingkan negara lain dengan tingkat penghasilan setara. Tulisan ini berpendapat bahwa faktor kunci yang menjelaskan rendahnya kualitas sumber daya manusia berhubungan dengan ketiadaan strategi yang terfokus dan jelas untuk mengembangkan sistem pendidikan Indonesia. Tulisan ini menilai kondisi kekinian dari pengembangan sumber daya manusia Indonesia dengan fokus khusus pada sektor pendidikan. Agar dapat mengoptimalkan manfaat dari bonus demografi, Indonesia perlu membenahi sistem pendidikan dan pelatihan keterampilan. Sistem pendidikan dan pelatihan keterampilan yang lebih baik akan menunjang upaya pengentasan kemiskinan dan pengurangan pengangguran muda. Efektivitas pengeluaran pemerintah di sektor pendidikan perlu ditingkatkan guna meningkatkan kualitas pendidikan. Indonesia perlu mengintegrasikan rencana pembangunan sumber daya manusia dengan master plan perekonomian.
\end{abstract}

Kata kunci: Sumber Daya Manusia; Kemiskinan; Pengangguran; Pendidikan; Pembangunan

JEL classifications: I25; O15

\section{Introduction}

After the Asian financial crisis in 1997-1998, Indonesia has been able to maintain its economic growth at 6 percent per annum on average. This sustained economic growth has contributed to Indonesia's improved economic and social develop-

* Corresponding Address: Pusat Penelitian Ekonomi (P2E) LIPI, Widya Graha Lt. 4, Jl. Jend. Gatot Subroto No. 10, Jakarta. E-mail: latif_adam@yahoo.com.au.

**E-mail: siwage@yahoo.com. ment indicators. Between 2000 and 2011, Indonesia's GDP per capita has increased from US $\$ 2,000$ to US $\$ 3,600$, and the poverty rate has decreased from 19.1 percent to 12.5 percent (Dirjen Anggaran 2013).

Despite these impressive achievements, Indonesia's economic and social development, however, still lags behind those of its East Asian neighbors, including South Korea, Taiwan, Singapore, Thailand, and Malaysia. Several factors have been identified as the cause of why Indonesia's economic and social development has not been as im- 
pressive as those of its more developed and richer Asian neighbors. One key factor relates to the lack of focus and clear strategies to develop its education sector, which adversely affects its human capital development. The country's education system, in various ways, has not been conducive to support the development of human capital. This is because Indonesia's education policies tend to be supply-driven rather than demand-driven. Lack of understanding of the characteristics, the needs, and the problems of human capital is the main culprit. These supply-driven policies are inadequate to respond to market demand and often they are poorly tailored for developing the needed skills and knowledge accumulation (Di Gropello, Kruse and Tandon 2011).

The 2011 Human Development Index (HDI) Report ranked Indonesia 124th out of 187 countries surveyed. The report indicates that the poor quality of human capital in Indonesia can cost the country to lose its growth potential. Without clear focus and strategies to reform its education system, Indonesia may fail to benefit from its demographic bonus. The latter is defined as the state where the ratio of productive-age population is greater than the non-productive one. Therefore, Indonesia needs to focus on improving its education and skill-training system in order to benefit from its demographic bonus. With better human capital, Indonesia can sustain its economic growth and support its goal to reduce poverty and unemployment. In addition, Indonesia also needs to consider how to reduce huge disparities in terms of education outcomes throughout the country. Under the Economic Master Plan for the Acceleration and Expansion of Economic Development (MP3EI), the government puts human capital as one of the three pillars for Indonesia's long term development. To be successful, the MP3EI must be accompanied with clear policies and strategies on how to develop human capital to support country's economic development.

Ironically, despite stating the importance of human capital in the country's economic masterplan, the government still allocates more public fund on fuel subsidy compared to education, health, and social protection. For example, in 2014 Indonesia will spend about 3.4 percent of its GDP (around Rp246.5 trillion) on fuel subsidy. At the same time, it will only spent Rp134.5 trillion on poverty reduction programs, Rp70.5 trillion on the health sector, and Rp91.8 trillion on social assistance programs (Dirjen Anggaran 2014). The government's rationale on giving priority to fuel subsidy in order to help the poor is very misleading. Several studies have shown that the fuel subsidy does not benefit the poor, since the bulk of the subsidy goes to the non-poor community (P2E-LIPI 2008a; World Economic Forum 2013).

This paper tries to assess the current state of human capital development in Indonesia with a particular focus on the education sector. We analyzed the national labor force survey data to examine some indicators of human capital in Indonesia, including the education profile of the workforce, inequality in education and unemployment rate. The key finding reiterates previous studies ${ }^{1}$ that found poor education outcomes in Indonesia were due to low quality of teaching, high drop-out rate among the disadvantage group, and inefficient public financing among others. The paper argues that Indonesia needs to integrate its human capital development plan into its long-term development strategy. Section two describes the current state of human capital in Indonesia with a particular focus on the education sector. Section three illustrates the positioning of human capital in the context of the economic master plan. Section four provides policy recommendations.

\section{Literature Review}

\subsection{Current Situation of Human Capi- tal in Indonesia}

\subsubsection{Poor Quality of Human Resources}

If we refer to Indonesia's human development index, Indonesia's human resources rank relatively low compared to other countries with the same level of income per capita. In a UNDP (2011) report on human development, out of 187 countries surveyed, Indonesia only ranked 124 in terms of the human development index (Table 1). The human development index measures the quality of human resources in one country based on three components, namely the education index, health index,

\footnotetext{
${ }^{1}$ See for example Di Gropello, Kruse and Tandon (2011), Suryadarma and Jones (2013), and World Bank (2013).
} 
Table 1: Human Development Index of Selected Countries, 2011

\begin{tabular}{|c|c|c|c|c|c|c|}
\hline HDI Rank & Country & $\begin{array}{r}\text { Human Development } \\
\text { Index (HDI) }\end{array}$ & $\begin{array}{r}\text { Life Expectancy } \\
\text { at Birth } \\
\text { (Years) }\end{array}$ & $\begin{array}{r}\text { Mean Years of } \\
\text { Schooling } \\
\text { (Years) }\end{array}$ & $\begin{array}{r}\text { Expected Years } \\
\text { of Schooling } \\
\text { (Years) }\end{array}$ & $\begin{array}{r}\text { Gross National } \\
\text { Income per Capita } \\
\text { (Constant } 2005 \\
\text { PPP\$) }\end{array}$ \\
\hline 1 & Norway & 0.943 & 81.1 & 12.6 & 17.3 & 47,557 \\
\hline 2 & Australia & 0.929 & 81.9 & 12.0 & 18.0 & 34,431 \\
\hline 3 & Netherlands & 0.910 & 80.7 & 11.6 & 16.8 & 36,402 \\
\hline 12 & Japan & 0.901 & 83.4 & 11.6 & 15.1 & 32,295 \\
\hline 13 & Hong Kong & 0.898 & 82.8 & 10.0 & 15.7 & 44,805 \\
\hline 15 & South Korea & 0.897 & 80.6 & 11.6 & 16.9 & 28,230 \\
\hline 26 & Singapore & 0.866 & 81.1 & 8.8 & 14.4 & 52,569 \\
\hline 61 & Malaysia & 0.761 & 74.2 & 9.5 & 12.6 & 13,685 \\
\hline 84 & Brazil & 0.718 & 73.5 & 7.2 & 13.8 & 10,162 \\
\hline 101 & China & 0.687 & 73.5 & 7.5 & 11.6 & 7,476 \\
\hline 103 & Thailand & 0.682 & 74.1 & 6.6 & 12.3 & 7,694 \\
\hline 112 & Philippines & 0.644 & 68.7 & 8.9 & 11.9 & 3,478 \\
\hline 124 & Indonesia & 0.617 & 69.4 & 5.8 & 13.2 & 3,716 \\
\hline 128 & Viet Nam & 0.593 & 75.2 & 5.5 & 10.4 & 2,805 \\
\hline 134 & India & 0.547 & 65.4 & 4.4 & 10.3 & 3,468 \\
\hline 138 & Laos & 0.524 & 67.5 & 4.6 & 9.2 & 2,242 \\
\hline 139 & Cambodia & 0.523 & 63.1 & 5.8 & 9.8 & 1,848 \\
\hline 149 & Myanmar & 0.483 & 65.2 & 4.0 & 9.2 & 1,535 \\
\hline 187 & Congo & 0.286 & 48.4 & 3.5 & 8.2 & 280 \\
\hline
\end{tabular}

and income per capita index. According to this composite index, the quality of Indonesia's human resources is lower than some of its ASEAN neighbors, including Singapore, Malaysia, Thailand, and the Philippines. In Asia, Japan, Hong Kong, and South Korea are the three top-ranked countries in terms of the human development index, implying the high quality of human resources in those countries.

This report suggests that the Indonesian government needs to put a greater effort to improve the country's human development programs if it wants to maximize the benefit from its demographic bonus. According to a World Bank report (2009), within the next two decades, Indonesia will experience a demographic dividend, in which dependency ratio (the ratio of young and elderly to working age population, 15-65 years old) will reach its lowest level before picking up again. According to recent government report, by 2020-2030, two third of Indonesia's population will be in the productive age, which means the country will have a large potential workforce to support the economy (Bappenas-BPS-UNPF 2014). In the region, Indonesia can be a hub for skilled labor-intensive industries. But in order to make the most of this potential, the country needs to prepare its workforce to be ready for entering a highly competitive labor market. This large, young and growing workforce also needs quality jobs, because otherwise there will be potential social conflicts in the future ${ }^{2}$. These social conflicts can in turn lead to political instability such as what, for instance, happened in Egypt and Chile.

Jimenez, Nguyen and Patrinos (2012) have stated that countries need to pay attention to the development of their human resources in order to avoid the "middle income trap". They have argued that many countries, such as Malaysia, lose momentum in making the transition from middle- to highincome status, as they fail to prepare their young workforce with the right skills.

In view of this potential, the next development challenge for Indonesia is how to prepare its large, young and growing workforce to respond quickly to the global market changes. This young workforce has to have good health, good education, useful skills, and a conducive environment to nurture their potential and develop their capacity. This is the reason why Indonesia needs to emphasize its human

\footnotetext{
${ }^{2}$ Manning and Purnagunawan (2011, p. 324) cited recent political turmoil in Egypt and Middle Eastern countries as examples of how high youth unemployment and the poor quality of jobs for youth in those countries have triggered huge social unrest and toppled the ruling government.
} 
resources development agenda and especially to prepare its education system so that it can respond to the global changes.

Education is one of the most important means for reducing poverty and sustaining economic growth. The role of education is important to prepare the quality human capital needed to build a strong society and competitive economy. Education is positively correlated to productivity, labor earnings and individual income. Empirical evidences have shown that the relationship between education and earnings is especially important for the poor as in many cases labor is their only significant asset (Card and Krueger 1996; Choi and Jeong 2003; Hawley 2004; Chen 2009).

Indonesia has been successful in increasing enrollment rates in primary education since the mid1970s. As a result of the government's sustained drive to expand the number of schools and teachers, the enrollment rate in primary schools rose from 72 percent in 1970 to 95 percent in 2010, while the rate for junior secondary education increased from 17 percent in 1970 to 68 percent in 2010. The senior secondary education enrollment rate increased to 46 percent from 17 percent during the same period ${ }^{3}$.

However, this impressive aggregate indicator has masked wide regional and systemic variations within the country. In Indonesia, disparities between provinces are quite large due to an unbalanced development strategy, which is biased toward Java. The Eastern part of Indonesia, including Nusa Tenggara Barat, Nusa Tenggara Timur, Maluku Utara, Maluku, West Papua, and Papua, has experienced wide development gap compared with that of Java. High disparities indicate that these regions need extra support from central government. For example, junior secondary net enrollment rates ranged from 49.7 percent in Papua to 75.4 percent in Yogyakarta, and at the senior secondary level, from 35 percent in Papua to 58.4 percent in Yogyakarta 4 .

Despite the success in enrollment expansion at the primary education level, inequalities remain at the junior secondary and senior secondary levels. In 2010, the net enrollment rate in junior secondary

\footnotetext{
${ }^{3}$ Author calculation based on Susenas 2010 data.

${ }^{4}$ Author calculation based on Susenas 2010 data.
}

school of the richest quintile of the population was about 10 percent higher than that of the poorest quintile $^{5}$. Nearly all children entered the early primary grades, due to the national compulsory basic education program. However, the Susenas data have shown that those who belong to the poorest income quintile drop out quickly. This category completes the fewest years of schooling. These patterns indicate the critical junctions in the school cycle when children from poor households begin to fall far behind.

To keep children from poor households finishing their school until senior high school and then continue to higher education is a very challenging task. Economic obstacles become the primary reason why these children drop out of school as early as junior high school. Most of the children from poor households work as family workers to help their parents earn a living. In this regard, policy intervention should be started by providing financial and non-financial assistance as well as increasing the parents' awareness to keep their children at school (Moeliodihardjo 2013). In addition, the government needs to strengthen the outreach programs to target students at all levels of education, including primary and secondary education. The education system needs to ensure that students are aware of their options as they progress through school. In communities where parents have no knowledge or experience of higher education, outreach programs will benefit from the inclusion of parents as well (Moeliodihardjo 2013).

There are several critical issues that Indonesia needs to tackle in order to move forward and achieve its higher goals in education. First issue is how to encourage all students to complete senior secondary level, that is to keep school-age children at school. The second issue is how to ensure that in poorer and disadvantaged regions, including remote and isolated regions, children have full and equal access to schools that provide a conducive learning environment and effective instruction. The third issue is how to provide education that is of acceptable quality and is relevant to the economy and society. The fourth issue is how to improve the effectiveness in education spending. Between 2008 and 2011, the budget on education has increased from Rp60.5 trillion to Rp91 trillion. However, as a

\footnotetext{
${ }^{5}$ Author calculation based on calculation from Susenas 2010 data.
} 
recent World Bank (2013) study points out, the increase in the budget is not correlated significantly with the better educational achievement. This indicates that the public fund has not been used effectively. The increase in spending goes mainly for increasing teacher's salary with no significant improvement of the students' learning outcomes.

Currently, the quality of schooling in Indonesia is lagging behind other countries. In fact, the rapid expansion of enrollment has yet to produce graduates with the consistently high quality of knowledge and skills needed to become a valuable input to economic production. International comparisons confirm the poor learning outcomes in Indonesia. The student's low learning outcomes are shown in the 2009 Program for International Student Assessment (OECD 2009: Table 2), which looks at how well 15 year olds score in mathematics, science, and reading tests. In these three subjects, Indonesia ranked very low, i.e. 61,60 , and 57 out of 65 countries in each respective subject.

On a proficiency scale from zero to six for mathematics, over 50 percent of Indonesian students did not reach level one. In reading, only 35 percent were able to complete more than the most basic reading tasks (World Bank 2008).

In higher education, the national system has expanded rapidly driven by increased number of secondary graduates and people's income. To respond to this demand for higher education, the number of private higher education institutions has increased to more than 3,100 institutions by $2012^{6}$. Higher education is important to contribute towards the expansion of a highly skilled workforce and the building of a strong foundation for the development of a knowledge-based economy. In this sector, a number of challenges need to be addressed.

In terms of higher education enrollment, Indonesia needs to catch up with other neighboring countries. The country needs to boost its currently low higher education enrollment rates of 24.7 percent to be on par with the other middle income countries (Figure 1). One of the key factors constraining higher education enrolment in Indonesia is the difficult transition from senior high school to university. There

\footnotetext{
${ }^{6}$ The government has been concerned about the expansion of private higher education institutions without clear quality control. In view of this concern, the DG of Higher Education has been stopping new application for new higher education institutions. See Kompas.com (2012)
}

is a relatively high drop-out rate after senior high school as high school graduates tend to choose to enter labor market early (Moeliodihardjo 2013).

In addition, noticeable inequalities have remained across income groups, in which only three percent of children from the poorest quintile were in higher education compared to about 40 percent in the richest quintile ${ }^{7}$. The government intervention through scholarship for poor students has not been quite successful due to difficulties in targeting the poor and the high criteria set for scholarship recipients (e.g. maintaining high GPA) which are often the main weakness of poor students.

Indonesia's universities are also largely isolated. They do not establish solid linkages with international higher learning network in research and development. They also have not strongly established strong linkages with business and industry network. Their curriculum is rigid and incompatible with industry's needs. As a result, the higher education produces graduates who are less able to meet the growing need for the more broad-based and flexible skills that the industry currently needs (Di Gropello, Kruse and Tandon 2011).

The demand for skills in Indonesia is expected to increase rapidly as the country embarks on a higher development stage. Indonesia is trying to shift its economy from a resource-based economy to a knowledge-based economy. This will bring Indonesia up the value chain in a wide range of sectors, with the help of its vast pool of human resources. In this aspect, there have been signs of increasing skills shortages, especially in larger, foreign-owned and exporting firms (Enterprise Surveys 2010). In order to meet the increasing demand for skills, Indonesia's education system must be able to produce not only a higher number of skilled workers (that is the share of workers with a certain level of education and training), but also relevant and useful skills (thinking skills, communication skills, learning skills, and adaptation skills). The education system will, therefore, need to provide graduates with complex competencies, which are the ability in using knowledge, skills and other abilities at work, and life-long learning, beyond technical skills. Based on a World Bank Enterprise Surveys (2010), there have been significant weaknesses in some thinking and behavioral skills

\footnotetext{
${ }^{7}$ Author calculation based on Sakernas 2008 data.
} 
Table 2: Student Performance on Mathematics, Science and Reading Tests, PISA 2009

\begin{tabular}{|c|c|c|c|c|c|c|c|c|}
\hline Country & $\begin{array}{l}\text { Mathematics } \\
\text { Score }\end{array}$ & $\begin{array}{l}\text { Mathematics } \\
\text { Rank Out of } 65 \\
\text { Countries }\end{array}$ & Science Score & $\begin{array}{l}\text { Science } \\
\text { Out of } \\
\text { Countries }\end{array}$ & $\begin{array}{r}\text { Rank } \\
65\end{array}$ & Reading Score & $\begin{array}{l}\text { Reading } \\
\text { Out of } \\
\text { Countries }\end{array}$ & $\begin{array}{r}\text { Rank } \\
65\end{array}$ \\
\hline China & 600 & 1 & 575 & 1 & & 556 & 1 & \\
\hline Singapore & 562 & 2 & 542 & 4 & & 526 & 5 & \\
\hline Hong Kong & 555 & 3 & 549 & 3 & & 533 & 4 & \\
\hline Korea & 546 & 4 & 538 & 6 & & 539 & 2 & \\
\hline Taiwan & 543 & 5 & 520 & 12 & & 495 & 23 & \\
\hline Japan & 529 & 9 & 539 & 5 & & 520 & 8 & \\
\hline Thailand & 419 & 50 & 425 & 49 & & 421 & 50 & \\
\hline Indonesia & 371 & 61 & 383 & 60 & & 402 & 57 & \\
\hline
\end{tabular}

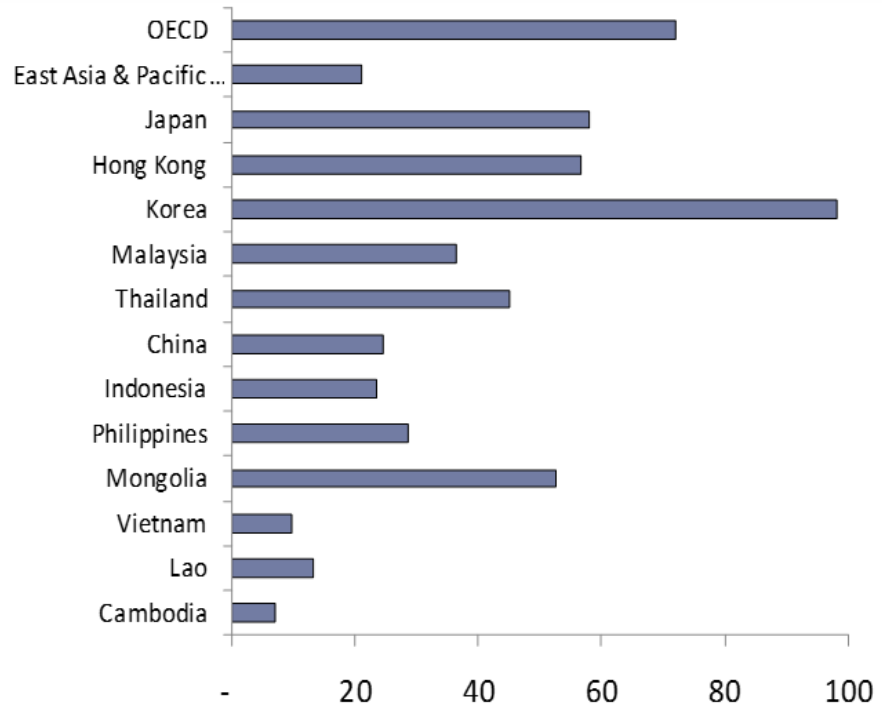

Figure 1: Higher Education Gross Enrollment Rate in Some Countries Source: UNESCO Institute for Statistics, 2009 
and in the capacity to apply in practice what has been learnt in school across all sectors (Di Gropello 2011) ${ }^{8}$.

\subsubsection{Poverty and Unemployment}

Indonesia is the fourth most populous country in the world with 237.5 million people ${ }^{9}$. Today, Indonesia is classified as a lower-middle income country, with a GDP per capita of around US $\$ 3,600$. The country has restored macroeconomic and financial stability after the 1997-98 Asian Financial Crisis. Economic growth has increased from 3.8 percent in 2001 to 6.5 percent in 2011.

However, an increase in economic growth is still not enough to reduce the number of poor in Indonesia, which still numbers around 30 million people. Therefore, reducing the poverty rate remains the greatest challenge for Indonesia's development agenda. According to the World Bank (2009), almost half of Indonesia's population is vulnerable to various aggregate and idiosyncratic shocks, including food price or fuel price shocks that can push them into poverty. During the 19971998 Asian Financial Crisis, the poverty rate in Indonesia jumped significantly to around 24.2 percent (Figure 2). It took about five years of sustained economic growth to reduce the poverty rate close to the level prior to the crisis. And there are significant number of people who are vulnerable to policy shocks. One may observe that when the government increased the fuel price in 2006, the poverty rate jumped to 17.8 percent.

After the financial crisis, progress in reducing poverty has been relatively slow. What is worrying is that higher levels of growth do not result in greater poverty reduction. With the GDP growth averaging at 7 percent per annum between 1990 and 1996, the headcount poverty fell nearly 4 percentage points, to 11.3 percent. But since 2003, poverty has been falling by only one percentage point despite the fact that growth has been averaging over 5 percent per annum (World Bank 2009).

\footnotetext{
${ }^{8}$ See http://www.enterprisesurveys.org.

${ }^{9}$ Based on 2010 population census conducted by the Central Bureau of Statistics (BPS).
}

Interestingly, the slowing down in the reduction of poverty rate has not matched the significant increase in anti-poverty budget (Adam 2011). Between 2000 and 2012, the anti-poverty expenditure- increased from Rp18 trillion to Rp99 trillion. However, during the same period the poverty rate decreased by only 7.6 percent, from 19.1 percent in 2000 to 11.5 percent in 2011, suggesting that anti poverty programs are not cheap (Table 3). One may want to test the effectiveness of anti-poverty programs by calculating the unit cost for reducing poverty. This calculation shows that it is more costly to reduce the number of poor from time to time. This may suggest two things: either we are facing the core of poverty group or the effectiveness of the poverty programs may be declining.

According to the World Bank (2003), there are several reasons why the government's anti-poverty budget has been largely ineffective in dealing with the incidence of poverty. First, weak institutional capability both at the central and the regional levels in designing, implementing, managing, and monitoring anti-poverty programs. Second, a poor poverty database which has accounted for the failure of the anti-poverty programs to reach the right targets. Third, most anti-poverty programs have been created on a project basis so that it is hard to ensure its sustainability after the project ended. Fourth, there have been some evidences of misuse of the anti poverty budget due to corruption. Fifth, there has been lack of participation and support from the community.

The change in the structure of the Indonesian economy can also be attributed to the slowing down in the reduction in the incidence of poverty. There is an indication in recent years that the nontradable sectors have become more dominant in supporting economic growth. In fact, up to 2010 the share of the non-tradable sectors in Indonesia's economy has been larger than that of the tradable sectors (Table 4). The problem is that the capacity of the non-tradable sectors in creating employment has not been as high as the tradable sectors, such as the agriculture and the manufacturing sector. In addition, there is some evidence that the growth in the non-tradable sectors has only benefited a small proportion of the population (Adam 2011).

Indonesia's 6 percent annual economic growth is still not enough to create more jobs in the formal 


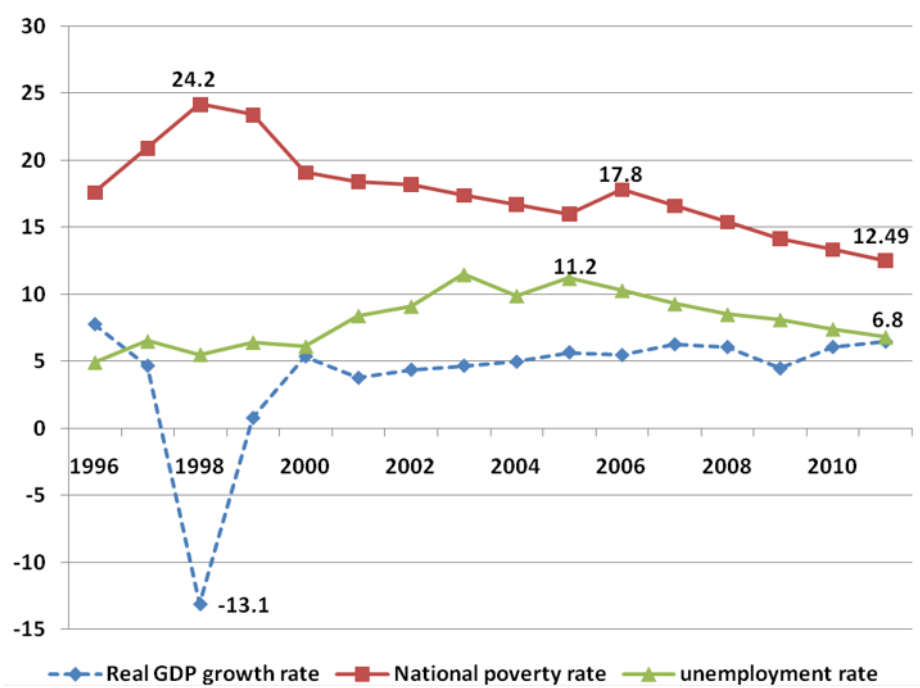

Figure 2: National Poverty Rate, Unemployment Rate, and Economic Growth Source: BPS, CEIC, and World Bank

Table 3: Poverty Programs Expenditure and Number of Poor, 2000-2010

\begin{tabular}{cccc}
\hline & \begin{tabular}{c} 
Expenditure \\
\cline { 2 - 4 }
\end{tabular} & $\begin{array}{c}\text { Number of Poor } \\
\text { (Rp Trillion) }\end{array}$ & $\begin{array}{c}\text { Poverty Rate } \\
\text { (Million) }\end{array}$ \\
\hline 2000 & 18.0 & 38.7 & 19.1 \\
2001 & 25.0 & 37.9 & 18.4 \\
2002 & 21.5 & 38.4 & 18.2 \\
2003 & 24.5 & 37.3 & 17.4 \\
2004 & 28.0 & 36.1 & 16.7 \\
2005 & 23.4 & 35.1 & 16.0 \\
2006 & 47.6 & 39.3 & 17.8 \\
2007 & 53.1 & 37.2 & 17.0 \\
2008 & 60.6 & 34.0 & 15.4 \\
2009 & 80.1 & 32.5 & 14.2 \\
2010 & 81.4 & 31.0 & 13.3 \\
2011 & 93.8 & 30.0 & 12.5 \\
2012 & 99.2 & 27.3 & 11.5 \\
\hline Source: Number of poor, BPS, Analisis dan Penghitungan \\
\multicolumn{4}{c}{ Kemiskinan 2010; Poverty programs budget, Ministry } \\
of Finance, Buku Saku APBN.
\end{tabular}

Table 4: Distribution of GDP by Sector, 2004-2010 (\%)

\begin{tabular}{lrrrrrrrr}
\hline & 2004 & 2005 & 2006 & 2007 & 2008 & 2009 & 2010 & 2011 \\
\hline Agriculture & 14.9 & 14.5 & 14.2 & 13.8 & 13.7 & 13.6 & 13.2 & 14.7 \\
Mining & 9.7 & 9.4 & 9.1 & 8.7 & 8.3 & 8.3 & 8.1 & 11.9 \\
Manufacturing & 28.4 & 28.1 & 27.8 & 27.4 & 26.8 & 26.2 & 25.8 & 24.3 \\
Total Tradable & 53.0 & 52.0 & 51.1 & 49.9 & 48.8 & 48.1 & 47.1 & 51.0 \\
\hline Utilities & 0.7 & 0.7 & 0.7 & 0.7 & 0.7 & 0.8 & 0.8 & 0.7 \\
Construction & 5.8 & 5.9 & 6.1 & 6.2 & 6.3 & 6.4 & 6.5 & 10.2 \\
Trade & 16.4 & 16.8 & 16.9 & 17.3 & 17.5 & 16.9 & 17.3 & 13.8 \\
Transport & 5.8 & 6.2 & 6.8 & 7.2 & 8.0 & 8.8 & 9.4 & 6.6 \\
Finance & 9.1 & 9.2 & 9.2 & 9.4 & 9.5 & 9.6 & 9.5 & 7.2 \\
Services & 9.2 & 9.2 & 9.2 & 9.3 & 9.3 & 9.4 & 9.4 & 10.5 \\
Total Non-tradable & 47.0 & 48.0 & 48.9 & 50.1 & 51.3 & 51.9 & 52.9 & 49.0
\end{tabular}

Source: BPS, Pendapatan Nasional Indonesia [National Income of Indonesia], various issues 
sector. Accordingly, the formal sector has not been as impressive as the informal sector in creating job opportunities. The problem is that the quality of job opportunities in informal sector has not been as good as those in the formal sector. This is particularly true in relation to the provision of social security, job security, and minimum wages. This suggests that creating more (quality) jobs in the formal sector becomes the next challenge for Indonesia.

After the 1997-98 Asian Financial Crisis, employment growth in Indonesia has failed to keep up with population growth. Part of the problems is because job creation in the formal sector has been slowing down due to various constraints. The World Bank reported that between 1999 and 2003, the percentage of the Indonesian workforce employed in the formal sector fell from 43 percent to 35 percent (World Bank 2009, p. 8). Rigidity of the labor regulations has been blamed for constraining job creation in the formal sector (Manning and Roesad 2007; World Bank 2010a).

The open unemployment rate stood at 6.8 percent in 2011. This unemployment rate is mostly contributed by youth unemployment (workforce aged 15 to 24). Based on the recent Labor Force Survey (Sakernas 2010) conducted by the Central Bureau of Statistics (BPS), the unemployment rate among young people under the age of 25 with high school and college degrees reached more than 30 percent (Table 5). What is of particular concern is that this high youth unemployment rate has been quite persistent over time.

\subsection{Changes in the Labor Market}

Traditionally, the agricultural sector used to be the safety net during the employment crisis, in which large numbers of workers were pushed into the agricultural sector. By 2003, agricultural employment had returned to 1991 levels. Most of the increase in agricultural employment came from the movement of workers out of the service sector, when the latter was the driver of the pre-crisis expansion. At present, the situation has been reversed. Non-agricultural employment has started to grow rapidly after 2003 and the agricultural employment has fallen to its lowest level since 1997. By 2010, less than 40 percent of the national workforce was employed in agriculture. The services sectors have become more and more important in absorbing the country's workforce (Figure 3).

According to the World Bank (2009, p. 9), the average productivity in the agricultural sector has been significantly low compared with the average productivity of the services sector and the productivity of the manufacturing industry. Interestingly, despite the recent decline in the share of the workforce engaged in agricultural employment, there have been no indications of productivity improvements in this sector. A large number of Indonesia's workforce still depends for its livelihood on low-productivity activities in agriculture and related areas.

In order to reduce poverty and create more employment, the government should pay more attention to promote the manufacturing sector. The manufacturing sector has a higher elasticity than other sectors to create job opportunities (P2E-LIPI 2008b). Adam (2011) has shown that the capacity of the manufacturing sector in eliminating poverty is 1.3 times higher than that of the agricultural sector and 3.2 times higher than that of the nontradable sectors.

He argues that there are two possible reasons why the manufacturing sector may have a better capacity than the other sectors in eliminating poverty. First, the terms of trade of manufactured products tends to increase continuously against other sectors' products, such as agriculture and mining. This suggests that on average the income level of workers in the manufacturing sector is relatively higher than workers in the agricultural and the mining sectors.

Second, the manufacturing sector has implemented several rules and regulations to protect labor in this sector, including through social security, regional minimum wages, and protection against layoffs. These rules and regulations ensure that quality of job in the manufacturing sector is relatively better than those in the other sectors. More importantly, firms' compliance to the labor rules and regulations is better in the manufacturing sector if compared with the other sectors.

From a human capital perspective, the first important step that the Indonesian government should take to promote the manufacturing sector is to enhance the productivity of the workforce by improving the education and training system. Improving the skill and education of the workforce will be the 
Table 5: Labor Market Conditions

\begin{tabular}{lrrrr}
\hline & \multicolumn{2}{c}{ All Ages (15+) } & \multicolumn{2}{c}{ Youth (15-24) } \\
\cline { 2 - 5 } & 2005 & 2010 & 2005 & 2010 \\
\hline Working age population (million) & 158 & 172 & 42 & 41 \\
Participation rate (\%) & 67 & 68 & 53 & 49 \\
Unemployment rate (\%) & 11 & 7 & 33 & 21 \\
& & & & \\
Employed population (million) & 94 & 108 & 15 & 16 \\
Formal sector (\%) & 37 & 40 & 41 & 46 \\
Informal sector (\%) & 63 & 60 & 59 & 54 \\
Urban (\%) & 40 & 42 & 39 & 44 \\
& & & & \\
By major sector & 44 & 38 & 41 & 32 \\
Agriculture (\%) & 19 & 19 & 26 & 25 \\
Industry (\%) & 37 & 42 & 34 & 43 \\
Services (\%) & 100 & 100 & 100 & 100 \\
\hline
\end{tabular}

Source: BPS, Sakernas (National Labor Force Survey)

Note: Adapted from Manning and Purnagunawan (2011, p. 324).

$\left(^{*}\right)$ The formal sector includes all wage employees and selfemployed people in the non-agricultural sector who engage family workers. The informal sector covers all family workers, self-employed people who do not engage family workers, and self-employed people working in agriculture who engage family workers.

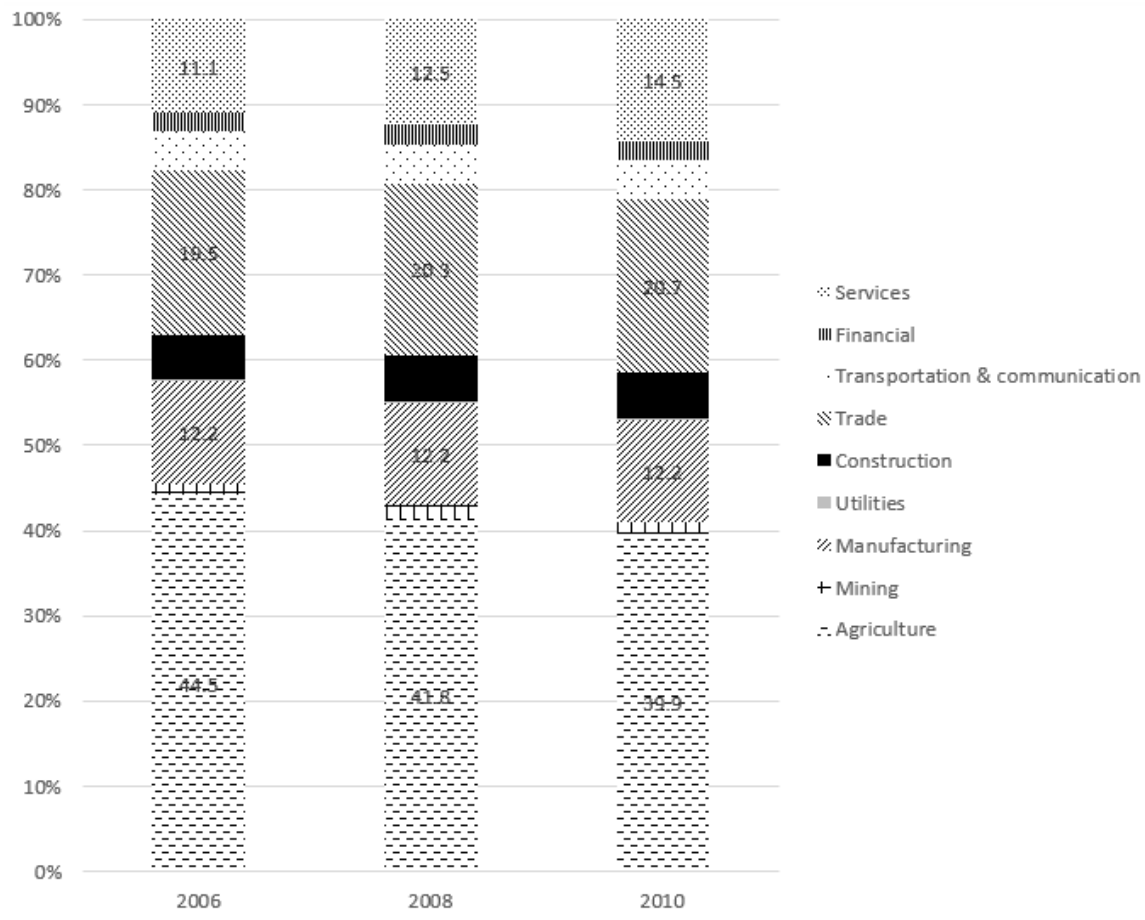

Figure 3: Structure of Workforce by Sectors Source: Sakernas, BPS 
key to prepare more productive workers for the manufacturing industries. At the same time, the government also needs to address the demandside problems. This means that the government should maintain and intensify its efforts to reform its industrial policy, so as to create a more competitive, favourable and open economic environment. This can be done through revising or abolishing unsound regulations, improving the ease of doing business, and reducing red tape. The government could also help the sector to reduce its production costs by eliminating taxes and tariffs on inputs, providing efficient ports and customs clearance, and removing nuisance charges (James, Ray and Minor 2003). In addition, the government should also provide more access for the manufacturing firms to sources of capital (e.g. bank/finance) so that this industry can attract new investment to replace its obsolete machines and other equipments (Adam 2008).

\section{The Role of Human Capital for Long-term Growth}

In its Master Plan for the acceleration and expansion of economic development of Indonesia (MP3El), the government states that it aims to achieve the following objectives. First, transforming the Indonesian economy into one of the 10 major economies in the world by 2025. Second, strengthening the foundations of the Indonesian economy to adapt to the dynamics of regional and global economy. Third, reducing disparities among the regions. Fourth, synergizing regional and sectoral economic development. Fifth, accelerating the improvement and equitable distribution of incomes.

To achieve these objectives, MP3El is formulated on the basis of three main pillars. First, the development of six economic corridors to foster centers of growth in each major island by developing leading resource-based industrial clusters. Second, the development of national connectivity to build synergies between those centers of growth through better international and regional connectivity. Third, the development of human resources capability and science and technology capacity to support and complement the development of economic corridors and national connectivity by improving the capabilities of Indonesia's human re- sources and increasing investments in research and development.

MP3EI also recognizes the need to structurally transform the economy by increasing secondary and tertiary economic activities. This goal will be achieved through rapid industrialization. There are four components to achieve the economic development goals: (i) increasing investment in infrastructure and manufacturing; (ii) increasing economies of scale; (iii) increasing human capital development; and (iv) raising economic productivity. Through these four components, the government aims for significant improvement in the poverty and human development indicators.

As stated explicitly in MP3EI, human capital development is urgently required to support the rapid transformation of Indonesia's economy. To this end, the government indicates its willingness to improve the quality of human capital by having more responsibility towards implementing a social safeguard system to ensure that the benefits of economic development is widely shared among the people. In implementing a social safeguard system, the government will provide: First, social safeguards in the form of targeted economic assistance for the poor, and in the form of universal social insurance for the public. Second, economic assistance to be executed in the form of subsidies and cash transfers targeted to the poor. Third, universal social insurance to be implemented through the combination of private and community funding.

Efforts to improve the quality of human capital will also be carried out by alleviating poverty based on a broad framework of creating new employment opportunities. To this end, MP3EI will address four main issues as follows. First, improving the availability and access to education and skills training to increase national productivity. Second, the creation of formal employment opportunities that protect the workers, and which will be implemented based on industrial relations that support fairness between workers and employers. Third, protection of Indonesian workers, as part of a social safeguard framework, is given to both the formal and informal sectors. Fourth, improving employment and industrial relation regulations to be supportive of both employers and employees.

In addition, the framework of alleviating poverty in MP3El is designed to be more open sources. This means that the strategy to alleviate poverty 
should be done through a coordinated effort between the government and society, in which each party plays a specific role. First, the role of society and businesses should be directed toward partnerships with local governments to solve the real problems of poverty specific to a certain region. Second, businesses can help to reduce poverty by focusing on specific areas through the implementation of corporate social responsibility (CSR) programs. Third, the central government further coordinates the activities of government, communities and regions.

While the role of MP3El in promoting human capital cannot be ignored, various issues in the master plan need more clarification. First, MP3EI is still lacking a specific implementation plan. There are four key issues in human capital development, which are interlinked: (i) population; (ii) education; (iii) health; (iv) labor force. Unfortunately, the MP3EI has no clear explanation of how these four key issues will be integrated to achieve a better result in human capital development for the purpose of supporting the rapid transformation of the Indonesian economy.

In addition, MP3EI does not specifically address regulatory bottlenecks that have been blocking investment in human capital for years, such as competing regulatory jurisdictions, ineffective fiscal regimes, and the slow disbursal of public funds. In fact, MP3EI was largely written by the same government bureaucrats who have been unable or unwilling to confront these issues for many years.

According to MP3El, formal employment will be created by promoting 22 major activities in six economic corridors spread across Java, Sumatra, Kalimantan, Sulawesi, Bali, NTB, Maluku-Papua. Of the 22 major activities, most are dedicated for non-agricultural employment. Moreover, of the six economic corridors, there are only two corridors that are focused on the development of agriculture (Sulawesi and Maluku-Papua), while the remainder are focused on manufacturing industry, mining, technology and so forth.

As explained previously, by 2010 , about 40 percent of the national workforce was employed in agriculture (Figure 3). The educational level of most Indonesian workforce is elementary school graduate with a low skill-base. Therefore, the objective of MP3El to create employment to a large extent in the non-agricultural sectors does not match with the current characteristics of labor supply.

Education should be a solution to deal with the above problem. This means that education should be able to improve the competencies of the labor force to be in line with the creation of employment in the non-agricultural sectors. The problem is that the educational system in Indonesia is not based on regional specificity. As MP3EI divides Indonesia into six economic corridors, the educational system should be adjusted to achieve a closer conformity with the human resources needed in each corridor. This suggests that the implementation of MP3EI should pay more attention to developing education and training system which is best suited to the regional abundance resources.

\section{Policy Recommendation}

Conceptually, the development of human capital has always been stated as the top government priority in Indonesia. This is emphasized in all key government documents, including the Long Term Development Plan (RPJP) 2005-2025, the Medium-Term Development Plan (RPJM) 20092014, and the latest Master Plan for Acceleration and Expansion of Economic Development of Indonesia (MP3EI). In order to implement these plans, the government has launched several policy instruments to promote human capital supported by various ministries and non-ministry institutions.

To support these policy instruments, the government has also allocated and increased its budget. For example, government spending for education since 2009 has been mandated by constitutional law to be at least 20 percent of total government expenditure. In addition, between 2000 and 2010, anti-poverty expenditure has been increased by almost fivefold (from Rp18 trillion to Rp86.1 trillion), while health expenditure rose by more than sevenfold (from Rp2.6 trillion to Rp18.8 trillion).

However, as explained previously, there has been a strong indication that numerous policy instruments and a significant increase in the government expenditure have been largely ineffective in promoting human capital in Indonesia. This suggests that to meet its vision, that is to give priority to the human capital development, the Indonesian government has to take various actions to improve and 
strengthen its policy instruments.

The first important action that the government should take is to minimize overlapping and contradicting policy instruments due to the involvement of various ministries and non-ministry institutions in promoting human capital. Better coordination among various ministries and non-ministry institutions under the strong leadership of the President will be the key to solve this problem. In addition, the government should create a comprehensive mechanism to ensure that the budget is spent effectively and used optimally in improving quality of human capital. In this case, monitoring and evaluation mechanism should be strengthened and there should be a clear reward and punishment mechanism in improving the quality of institutional performance.

In view of these programs, the government should revitalize the family planning program (Keluarga Berencana) to control population growth. During 2000-2010, the growth of population was 1.49 percent per year on average, while the growth of rice production was only 1.39 percent per year. The fact that population growth during this period was higher than that of rice production placed the government in a politically difficult situation. The reason was that the government was under pressure to ensure that rice supply was always enough to stabilize food prices and reduce their volatility. Moreover, the high growth of population puts extra pressure on the government to provide sufficient facilities and infrastructure to accommodate the needs of people. This, particularly in urban areas, has resulted in various social and environmental problems, including poor housing, unclean water, increase solid waste, drainage problems, etc.

In addition, the government has put an effort to encourage people to participate actively in alleviating poverty through the National Program of Community Empowerment (Program Nasional Pemberdayaan Masyarakat). Even though this effort should be appreciated, the government should go beyond such an empowerment program. Several measures that need to be taken further by the government are: (1) improving the institutional capability, both at central and regional level in designing, implementing, managing, and monitoring the program; (2) strengthening the poverty database to enable the program to succeed in reaching the right targets; and (3) encouraging the implementa- tion of the program based on local characteristics. This means that implementation of the program should not be generic. Rather, it can vary from one region to another depending on the economic, social, and cultural characteristics of each region.

Improving the quality of public education and training system is another action that the government should do to promote human development. To improve the quality of public education and training system, it is recommended that the government address the following issues: (1) preventing early dropouts and improving the quality of basic education; (2) improving cognitive skill of students before they reach senior secondary education and ensuring an adequate supply of senior secondary schools in the desired stream; (3) strengthening basic skill and competencies for secondary school graduates through improvements in the educational quality and shifting vocational education to a later stage; (4) exploring alternative modes of delivering vocational education, increasing practical training and linkages with the private sector; (5) improving the capacity of the non-formal training system to compensate for the lack of skills as well as provide a viable way to train unskilled workers and retrain and upgrade the skills for educated workers; and (6) strengthening quality assurance mechanisms through the establishment of competency-based standards and a clear and enforceable accreditation mechanism.

Finally, to ensure the successful implementation of MP3EI, the government should have a strong commitment to synchronize the development of the six economic corridors and the development of education and R\&D activities. This suggests that the expansion of secondary and tertiary education, including vocational, should be based on the criteria of human capital required to promote economic activities in each corridor. In other words, the expansion of education system should be linked and matched to the priority development in the six economic corridors. It is recommended therefore that demand-driven principles should be the main foundation to develop educational system.

\section{Conclusion}

This paper has examined and discussed the current state of human capital development in In- 
donesia. This examination indicates that Indonesia's economic and social policies, in various ways, have not been conducive to support the development of human capital. Accordingly, Indonesia's human resources quality is lower than some of its more advanced ASEAN neighbors, such as Singapore, Malaysia, Thailand, and the Philippines.

The poor quality of human capital should encourage the Indonesian government to put more efforts in improving the country's human capital development. We recommend that the government puts priority in improving the effectiveness of existing human resources development programs including education, skill training and poverty eradication. In addition, the government needs to consider how to control the growth of the population and increase the number of jobs in the formal sectors.

Finally, in order to improve human capital quality in Indonesia, the government needs to take several actions. First, designing a long-term human capital development plan which has to be committed to by the current and future governments. Second, integrating human capital development into its development masterplan. Third, improving the quality of economic growth to tackle the problem of unemployment and poverty through promoting manufacturing and other tradable sectors.

\section{References}

[1] Adam, L 2008, 'Prasyarat Dasar [Basic Requirements]' in Model Peningkatan Daya Saing Perekonomian Indonesia [Model on Improvement in Competitiveness in the Indonesian Economy], ed MT Sambodo, LIPI Press, Jakarta, pp. 61-86.

[2] Adam, L 2011, 'Hubungan Diantara Pertumbuhan Ekonomi dan Penurunan Kemiskinan', Jurnal Ekonomi, vol. 16, no. 1, 79-93.

[3] Bappenas-BPS-UNPF 2014, Proyeksi Penduduk Indonesia [Indonesia Population Projection] 2010-2035, Badan Perencanaan Pembangunan Nasional-Badan Pusat Statistik-United Nations Population Fund, Jakarta. Available from: <ww.bappenas.go.id/files/5413/9148/ 4109/Proyeksi_Penduduk_Indones ia_2010-2035.pdf >. [12 December 2013].

[4] BPS, Analisis dan Penghitungan Kemiskinan 2010, BPS, Jakarta.

[5] BPS, Pendapatan Nasional Indonesia 2004-2011, BPS, Jakarta.

[6] BPS, Sakernas 2008, BPS, Jakarta.

[7] BPS, Sakernas 2010, BPS, Jakarta.

[8] BPS, Susenas 2010, BPS, Jakarta.

[9] Card, D \& Krueger, A 1996, 'Labor Market Effects of School Quality: Theory and Evidence', in ed G Burtless,
Does Money Matter? The Link Between Schools, Student Achievement and Adult Success, Brookings Institution, Washington, DC, pp. 97-140.

[10] CEIC, https://www. ceicdata.com/en.

[11] Chen, D 2009, 'Vocational Schooling, Labor Market Outcomes, and College Entry', Policy Research Working Paper, WPS4814, Human Development Sector Department, East Asia and Pacific Region, World Bank, Washington DC. Available from: <https://openknowledge.worldbank.org/bitstream/ handle/10986/4012/WPS4814. pdf ? sequence=1> [12 December 2013]

[12] Choi, K-S \& Jeong, J-H 2003, 'The Rising Returns to Education and Skill-Biased Technological Change in Korea: 1983-2000, Department of Economics, Yonsei University, Seoul, Korea.

[13] Di Gropello, E 2011, Putting Higher Education to Work: Skills and Research for Growth in East Asia, World Bank East Asia and Pacific Regional Report, The World Bank, Washington, DC.

[14] Di Gropello, E, Kruse, A, \& Tandon, P 2011, Skills for the Labor Market in Indonesia: Trends in Demand, Gaps, and Supply, World Bank, Washington DC.

[15] Dirjen Anggaran 2013, Seputar APBN: Anggaran Kemiskinan 2011-2015, Direktorat Jenderal Anggaran Kementerian Keuangan RI. Available from: <http://www.anggaran. depkeu.go.id/dja/ edef - seputar - list . asp? apbn=misk in >. [10 May 2013].

[16] Dirjen Anggaran 2014, Seputar APBN: Anggaran Pendidikan 2011-2015, Direktorat Jenderal Anggaran Kementerian Keuangan RI. Available from: <http://www.anggaran.depkeu.go.id/dja/ edef-seputar-list.asp?apbn=miskin>. [29 August 2014].

[17] Enterprise Surveys 2010, Indonesia (2009), World Bank Group. Available from: <http://www. enterprisesurveys.org/data/exploreeconomies/ 2009/indonesia [12 December 2013].

[18] Hawley, JD 2004, 'Changing Returns to Education in Times of Prosperity and Crisis, Thailand 1985-1998', Economics of Education Review, vol. 23, no. 3, 273-286.

[19] James, WE, Ray, DJ, \& Minor, PJ 2003, 'Indonesia's Textiles and Apparel: The Challenges Ahead', Bulletin of Indonesian Economic Studies, vol. 39, no. 1, 93-103.

[20] Jimenez, E, Nguyen, V, \& Patrinos, HA 2012, 'Stuck in the Middle? Human Capital Development and Economic Growth in Malaysia and Thailand', Policy Research Working Paper, WPS6283. Education Unit, Human Development Network, The World Bank, Washington, DC. Available from: <https://openknowledge.worldbank.org/bitstream/ handle/10986/16334/wps6283. pdf ?sequence=1>. [12 December 2013].

[21] Kompas.com 2012. Moratorium untuk PTS Baru. Selasa, 21 Agustus 2012. Available from: <http: //edukasi.kompas.com/read/2012/08/21/12322020/ Morator ium. untuk. PTS. Baru>. [27 November 2013].

[22] Manning, C \& Roesad, K 2007, 'The Manpower Law of 2003 and Its Implementing Regulations: Genesis, Key Articles and Potential Impact', Bulletin of Indonesian Economic Studies, vol. 43, no. 1, 59-86.

[23] Manning, C \& Purnagunawan, RM 2011, 'Survey of Recent Development', Bulletin of Indonesian Economic Studies, vol. 47, no. 3, 303-332.

[24] Ministry of Finance, Buku Saku APBN, Jakarta. 
[25] Moeliodihardjo, BY 2013, Equity and Access in Higher Education, World Bank, Jakarta.

[26] OECD 2009, Programme for International Student Assessment (PISA) 2009, Organisation for Economic Cooperation and Development (OECD), France.

[27] P2E-LIPI 2008a, Problema Pengangguran dan Kemiskinan di Tengah Gejolak Harga BBM: Telaah Kritis Kebijakan dan Solusi Alternatif [Problems of Unemployment and Poverty Amid Fuel Price Volatility: Critical Review and Policy Alternative Solutions], Press Release, July 16, 2008. Pusat Penelitian Ekonomi Lembaga IImu Pengetahuan Indonesia, Jakarta.

[28] P2E-LIPI 2008b, Pertumbuhan Ekonomi Naik, Industri Stagnan [Economic Grow, Manufacturing Stagnant], Press Release December 19, 2008. Pusat Penelitian Ekonomi Lembaga Ilmu Pengetahuan Indonesia, Jakarta.

[29] Suryadarma, D \& Jones, GW 2013 (Eds.), Education in Indonesia, Institute of Southeast Asian Studies, Singapore.

[30] UIS 2009, UNESCO Institute for Statistics 2009, UNESCO Institute for Statistics (UIS) - United Nations Educational, Scientific and Cultural Organisation (UNESCO). http:// www . uis . unesco.org/.

[31] UNDP 2011, Human Development Report 2011: Sustainability and Equity: A Better Future for All. United Nations Development Programme, New York. Available from: <http://hdr.undp.org/sites/default/ files/reports/271/hdr_2011_en_complete.pdf>. [12 December 2013].

[32] World Bank 2003, World Development Report 2003: Sustainable Development in a Dynamic World: Transforming Institutions, Growth, and Quality of Life, A copublication of the World Bank and Oxford University Press, Washington, DC. Available from: <https://openknowledge. worldbank. org/bits tream/handle/10986/5985/WDR\% $202003 \% 20$ - \%20English.pdf? sequence=1>. [12 December 2013].

[33] World Bank 2008, Indonesia: Economic and Social Update, April 2008, World Bank. Available from: <http://siteresources.worldbank.org/ INT INDONESIA/Res ources/Country-Update/ecsos . update . apr2008.pdf>. [12 December 2013].

[34] World Bank 2009, Indonesia Development Policy Review: Enhancing Government Effectiveness in a Democratic and Decentralized Indonesia, November 2009, The World Bank. Available from: <http://www-wds.worldbank. org/external/default/WDSContentServer/WDSP/IB/ 2010/03/12/000333037_20100312013325/Rendered/ PDF /534510WP0 ind on10Box345611B01PUBLIC1 . pdf > . [12 December 2013].

[35] World Bank 2010, Indonesia Jobs Report: Towards Better Jobs and Security for All: Executive Summary, The World Bank Office, Jakarta. Available from: <http://www-wds.worldbank.org/external/ default/WDSContentServer/WDSP/IB/2010/08/ 31/000333038_20100831001600/Rendered/PDF / 563480WPOIndon1cut ive0SummaryOF INAL.pdf $>$. December 2013].

[36] World Economic Forum 2013, Lessons Drawn from Reforms of Energy Subsidies, World Economic Forum, Geneva. Available from: <http: //www3 . wef orum.org/docs/GAC13/WEF_GAC13 Less onsRef ormsEnergySubsidies_Report.pdf $>$. [12 December 2013]. 